\title{
Accepted version: Child soldiers as peace-builders in Colombian peace talks between the government and the FARC-EP
}

\section{Patricia Nabuco Martuscelli}

International Relations Research Centre, University of São Paulo, São Paulo, Brazil

ORCID ID: https://orcid.org/0000-0003-2611-2513

\author{
Rafael Duarte Villa \\ Department of Political Science and the Institute of International Relations, University of São \\ Paulo, São Paulo, Brazil
}

ORCID ID: orcid.org/0000-0002-8751-6020

\section{Contact}

Rafael Duarte Villa: rafaelvi@usp.br

\section{Notes on contributors}

Patricia Nabuco Martuscelli is a PhD candidate in Political Science at the University of São Paulo and a Visiting Researcher at the Carolina Population Center at the University of North Carolina at Chapel Hill. She is also a Research Associate in the International Relations Research Centre at the University of São Paulo.

Rafael Duarte Villa is Associate Professor of International Relations in the Department of Political Science and the Institute of International Relations and director of the International Relations Research Centre at the University of São Paulo. His articles have appeared in peer-reviewed journals such as the Contemporary Security Policy and Revista Brasileira de Política Internacional and he recently co-edited the book Power Dynamics and Regional Security in Latin America (Palgrave Macmillan, 2017).

\section{Acknowledgements}

We are grateful to the Carolina Population Center for training and general support, for the comments and suggestions of anonymous peer-reviewers, and for the comments of Victor Araújo and Mark Hamilton on previous versions of this article at the Conference of the International Security and Arms Control (division of the American Political Science Association) and 
International Security Studies Section (division of the International Studies Association), Washington DC, 2017.

\begin{abstract}
Children, especially girls, are considered victims in armed conflicts. Children who participate in conflicts, as combatants, sexual servants, spies, informants and messengers, may be considered perpetrators of atrocities. These two classifications of children in armed conflicts do not consider their roles as agents who may also participate in peace-building efforts. This paper analyses how children involved in armed conflicts are classified and represented in the current peace agreement between the Colombian government and the FARC-EP - the Revolutionary Armed Forces of Colombia-People's Army (Fuerzas Armadas Revolucionarias de Colombia-Ejército del Pueblo). We aim to understand if children are recognised in this peace process as participants and, in some capacity, as peace-builders. Dialoguing with the literature on critical security studies and childhood studies, we conduct a critical discourse analysis of the peace agreement documents. The study of the Colombian case enables an empirical analysis in which child soldiers are categorised as victims with the possibility of participating in peace-building and, at the same time, as potential challengers to the peace process.
\end{abstract}

Keywords: Colombia, final agreements, child soldiers, armed conflict, FARC-EP

\title{
Introduction
}

A situation of armed conflict, such as the Colombian one, which lasted more than 50 years, prevented at least three generations of children ${ }^{1}$ from living in a peaceful environment. Thus, a high proportion of the Colombian population grew up in a violent environment permeated by machismo, by the power of weapons and by the valourisation of force as a way of facing life and solving disputes. ${ }^{2}$ Because of this, children, especially girls, are traditionally classified as victims of armed conflicts and they tend to be considered as such in peace negotiations. However, as representatives of future generations, they bear the larger responsibility of constructing a durable peace. United Nations Security Council Resolution 2250 (2015) recognises the importance of youth (individuals between 18 and 29 years old) in peacekeeping, peace promotion and international security, including the prevention of future conflicts. ${ }^{3}$ Children and young people are fundamental for the sustainability of peace and the success of efforts in peacekeeping and peace-building. Peace 
agreements for a long internal conflict in a country should take into account that children have participated in the role of soldiers. The Cape Town Principles, adopted at the Symposium on the Prevention of Recruitment of Children into the Armed Forces and on Demobilisation and Social Reintegration of Child Soldiers in Africa, defines a child soldier as any person under 18 years old who is part of any regular or irregular armed force or group in any capacity including cooks, porters, messengers, sexual servants and all those who follow the armed groups without being a family member of adult combatants. ${ }^{4}$ Although girls tend not to be considered as child soldiers, it is important to note that they are participants in armed conflicts and in demobilisation programmes in the same way as boys.

The initial agreement to begin peace negotiations signed by the FARC-EP and the Colombian Government on 26 August 2012, in Havana, did not mention the issue of children nor the situation of those involved in the armed conflict. ${ }^{5}$ The Final Agreement for the Ending of the Conflict and the Construction of a Stable and Lasting Peace (Acuerdo Final Para La Terminación del Conflicto y la Construcción de una Paz Estable y Duradera), signed on 24 November $2016,{ }^{6}$ is the result of a complex peace negotiation to end one of the longest conflicts in the world. The document brings real possibility to recognise former child soldiers (including girls) as participants in the post-conflict environment. Besides that, the Colombian peace process is the first peace negotiation after the creation of the International Criminal Court (ICC). As a result, those who committed crimes present in the Rome Statute of the ICC must be punished by the Colombian authorities, otherwise the ICC has the authority to prosecute them since Colombia has accepted the ICC's jurisdiction. The use and recruitment of children under 15 years old is considered a crime of war under article 8 of the Rome Statute. ${ }^{7}$ For this reason, groups that recruit children tend to hide this practice.

The FARC-EP was one of the groups that used to recruit children while denying the practice. On 11 February 2015, in the middle of the peace talks, the guerrillas announced that they would not accept children under 15 years old into their ranks any longer and in November they raised the age to 18. In that moment, the FARC-EP was publicly confirming that they had been recruiting children up until that point. The group also confirmed that they had been committing this war crime when they signed the Final Agreement with the Colombian Government and agreed to release children from their ranks on 15 May 2016. Our research question addresses how children are constructed in the Colombian peace agreement and how children involved in the armed conflict are represented in the peace agreements. Then, it can be assessed whether children are considered victims, perpetrators, or if they can be considered active peace-builders in the process. By presenting a discussion of children in security studies, we analyse the Colombian peace agreement 
and the Special Agreement for the Release of Children, both signed between the Colombian Government and the FARC-EP. Studying the Colombian case enables an empirical analysis in which children involved in the armed conflict could be categorised ambiguously as victims, with the possibility of participating in the peace process and, at the same time, as potential challengers to the peace process.

The ways in which children and those involved in armed conflicts are defined in a peace agreement have important ramifications for how they will be seen during the peace process and in creating opportunities for their active participation and recognition as peace-builders. From a methodological point of view, the Colombian peace agreement is a central document leading towards an understanding of peaceful ideas and the paths for constructing peace as negotiated by the parties involved in the conflict. It may not be the optimal solution for the conflict, but it was the best possible outcome from the negotiation. This document will be the formal basis for peacebuilding. In this sense, the way children and child soldiers are classified will forecast the way these groups will be perceived during the post-conflict phase. If the document recognises clear possibilities for children's participation as peace-builders, there is a greater probability that children will effectively participate than if the document does not mention children at all. Thus, to understand how children involved in armed conflicts are perceived and if there is a real possibility for their participation in post-conflict peace-building, this article analyses the wording of the Colombian peace agreement and of the agreement to release children from FARC's ranks. We use a critical discourse analysis approach because the concepts used to describe children in these documents will impact on and create the post-conflict environment in which these children will live. Special attention will be given to the parts of the agreements that explicitly mention children and how they are conceptualised, as well as whether there is reference to any possibility of participation and consideration of their roles as peace-builders.

We chose the Colombian case because it is the first peace negotiation after the creation of the ICC. It is also a case in which the use and recruitment of child soldiers by an armed group is explicitly recognised through the signing of a special agreement to release children from their ranks.. Finally, the Colombian case reminds us that child soldiers are not an 'African problem' as they are so often perceived. The comparison of these documents and the methodology proposed will enable us to assess what children's roles in the post-conflict environment will be according to the principal agreement derived from the peace negotiations. This is a way to see if children are victims, threats to security, or agents and peace-builders in post-conflict situations. We also recognise that children can be agents in non-formal peace-building spaces and opportunities exist through community efforts and activities in schools. Those initiatives are important for the 
construction of a peace culture and long-lasting peace. While those programmes are not the focus of this article, we briefly mention some alternatives like this to exemplify other peace-building efforts where children were recognised as agents.

The article is organised into three sections. The first part presents a literature review on critical security studies related to childhood and children, especially child soldiers. The second section analyses the Colombian armed conflict up to the peace agreements between the government and the FARC, with special emphasis on the participation of child soldiers in the conflict and their insertion in the agreements. The third section presents the classification and representations of how Colombian children involved in the armed conflict are defined in the discourse of the Colombian agreements between the government and the FARC-EP.

\section{Literature review: critical security studies and children}

A new perspective in critical security studies dialoguing with Childhood Studies has been researching how children are represented in armed conflicts. Authors identify that children tend to be categorised as victims or, in the case of child soldiers, as direct threats to peace. ${ }^{8}$ However, these two approaches are not sufficient to understand the complex roles that children perform because it excludes their roles as agents and builders of peace. The same discussion can be seen in the works of Watson, who argues that children are agents in international relations because they consume, they work (meaning they are international agents in the economy), they participate (even though in limited capacity) and they fight. ${ }^{9}$ This section discusses the social construction of the concept of children and child soldiers and the implications for their participation as peace-builders. ${ }^{10}$

Brocklehurst recalls that children possess vital political capital and agency in the international system because they can be considered threats, models, investments, tools and resources through the appropriation of their bodies (use of their vulnerability) and minds, as well as the inability of the international community to enforce restrictions placed by outside agencies. ${ }^{11}$ Brocklehurst and Peters argue that non-governmental organisations (NGOs) working with child soldiers tend to define them as victims, lost children and problem children to bring attention and resources to their pledge and to help in the reintegration process. ${ }^{12}$ Besides that, the image of African child soldiers is useful for humanitarian discourses. ${ }^{13}$ Brocklehurst and Peters argue that children's narratives have become vital capital for diplomacy, justifying the need for intervention in countries with failed regimes, especially in the 1990s when the child-soldier figure became the symbol of intra-state conflicts. ${ }^{14}$ For the authors, all this attention to child soldiers would make them more likely to be heard than other children who were affected by armed conflicts. ${ }^{15}$ 
Children's experiences are shaped by the understanding that children are underdeveloped people, by the perception of what constitutes being a child and by the way individuals and groups set expectations on children. Children tend to be excluded as political and economic agents, but they are inserted in states' security and economic calculations as future labour, resources for war and instruments of national security. As the traditional definition of children places them away from politics, child soldiers are considered a political anomaly because they have military power and, at the same time, they are classified as victims that need humanitarian and political support. ${ }^{16}$

The crisis of child soldiers is a modern political crisis that has little to do with the number of children involved in conflicts. The use of child soldiers is not a new phenomenon and children were used during the period of the Crusades and during the Napoleonic wars. However, the increase in life expectancy, the change in the way children are socially categorised and the recognition of rights inherent to them, which must be guaranteed and respected by states, have brought focus to the issue of the use of child soldiers as an unacceptable practice that undermines the developmental potential of children and their countries. ${ }^{17}$ The child soldier enters a social condition that denigrates the accepted status of childhood. ${ }^{18}$ This would involve a sentimental symbolisation of children as the common abstract hope of humankind to solve future social problems created by adults. ${ }^{19}$ Child soldiers, as a social phenomenon, challenge not only comfort based on the nature of childhood, but also the traditional understandings of war and violence. ${ }^{20}$ Girl soldiers, in addition, challenge the comfort of the categories children and girls but they tend to be invisible in the gender-neutral category 'child soldiers'. ${ }^{21}$

Child combatants are a dilemma for adult society because engaging in conflict does not fit the category of child-related activities and the idea of vulnerability surrounding this group. As warriors are considered adults, minors involved in armed conflicts are often excluded from the benefits and protection associated with the traditional concept of children. ${ }^{22}$ On the other hand, participating in a war does not guarantee them full entry into the adult world, nor their recognition as active participants in their societies. In this view, child soldiers are posed as social and military aberrations that must be corrected by humanitarian assistance rather than as products and indicators of social inequalities that require structural changes. ${ }^{23}$

From this perspective, children's own decisions to participate in a conflict tend not to be recognised. One difficulty is how to consider children's voluntary recruitment in an armed conflict. This idea of voluntary recruitment can be complicated because children's decisions to participate in an armed conflict are taken in a situation of violence and violations of rights. Perhaps these children would not choose to volunteer if they were in a peaceful environment where all their rights were guaranteed. However, if a child has made the decision to participate in an armed group, s/he could 
make the same decision to be part of another armed group if s/he finds him/herself in the same position as the first recruitment. In that case, even if the possibility of a full 'voluntary recruitment' did not exist, children should be recognised as agents that have power to take decisions that affect their lives. This discussion of voluntary recruitment is especially useful for the Colombian case. Children are agents of change in the decision to become involved in an armed conflict but also with the possibility of creating peace.

During an armed conflict, children may be forced to make the calculus that "voluntary recruitment' is the best decision available. In this decision-making process, they consider structural factors like poverty and lack of protection frameworks. Besides that, this 'voluntary' act decreases the recruiters' work because abductions and rituals to break familiar and community bonds will not be necessary. Children that consider themselves volunteers are less prone to desert because they think that they are there by their own choices. Additionally, the logic that leads to this recruitment must be understood and addressed in disarmament, demobilisation and reintegration (DDR) processes because a child who volunteers once can do it again if facing the same conditions. That is why children's visions should be taken into consideration during the entire peace process.

Poverty is both a direct and indirect cause for children to become soldiers. ${ }^{24}$ Hunger, poverty and children's need to contribute to the family's budget may make parents offer their juniors for service in armed groups or parents may encourage them to volunteer to guarantee them regular meals, clothes and medical care. The lack of educational opportunities and vocational training may provide few employment alternatives for these minors, especially considering the armed conflict context where schools and day-care facilities are closed. ${ }^{25}$ When armies and armed groups are the only 'employers', this is the chosen 'alternative' taken by children as a last resort to support themselves and their families. In this way, to eliminate child soldiers' recruitment and also avoid other types of child labour, it is essential to provide adequate options and alternatives.

Where there is a total breakdown of family and social bonds, armed actors may be perceived as the only refuge and security providers for children. As a result, children would make a rational calculus that entering armed groups (that will provide them with food, clothing, medical care and security because they will be armed - considering the power sensation and the imagined benefits of the military life), ${ }^{26}$ is more advantageous than remaining an unarmed civilian unprotected by the state and depending on the armed actors' will. That means joining an armed group can be a desperate measure to obtain protection or social status. ${ }^{27}$ Many child soldiers volunteer because they calculate that eventually they will be forcibly recruited and, in this case, being a 'volunteer' may have benefits such as the possibility of choosing a commander and functions, while being forcibly recruited involves more costs. 
Some minors, especially girls, volunteer to escape an oppressive familiar context, sexual violation and abuse and bullying at home and school. ${ }^{28}$ From this perspective, children may perceive 'voluntary' conscription as a type of empowerment because with guns they will be respected and not victims of exploitation and abuses. Other causes that impact children's and youth's voluntary conscription are the search for adventure, identity and recognition, revenge, the model of the military life (the real or imaginary one) and male cultures that value militarism and to serve a religious, ethnic, ideological or political cause. ${ }^{29}$

Nosworthy notes that children are defined as vulnerable, victims of circumstance or delinquent troublemakers who threaten security. ${ }^{30}$ But these categories are not useful in understanding children's concerns and needs after a conflict. Societies, including the Colombian one, face many post-conflict security challenges, such as DDR programmes for former combatants, including children, removing landmines, re-organising their security forces, integrating armed groups into society, punishing crimes and atrocities, compensating victims and promoting reconciliation. But the largest one is avoiding the return of conflict. ${ }^{31}$ Nosworthy argues that children and youth are important to the sustainability of peace and that this is why they need to be occupied with and participating in activities that contribute to peace in their societies. ${ }^{32}$ Those activities involve formal peace-building processes but also informal programmes and activities.

This literature discusses different ways to classify children in general and child soldiers more specifically. In the next section, we analyse the Colombian case, an empirical situation where there are written definitions and interpretations of children in the armed conflict to verify how these children are categorised and the implications of these definitions for their potential to participate in peace-building processes.

\section{The Colombian case: peace negotiations and child soldiers}

Currently, the Colombian internal armed conflict is the only one on the American continent and the longest of this category in the world. Its longevity is only surpassed by the international conflicts between Israel and Palestine and India and Pakistan. ${ }^{33}$ There have been efforts by different governments to establish dialogue with the guerrillas, beginning in the 1980s with President Belisario Betancourt, where the first negotiations focused on the promotion of political-electoral participation of members of the FARC-EP. From this initial agreement, the political party 'Patriotic Union' was created by demobilised people from different guerrilla groups: the FARC-EP, the National Liberation Army (Ejército de Liberación Nacional - ELN) and other leftist militants of progressive sectors and of the Communist Party who had been excluded from politics since the 
National Front. ${ }^{34}$ The new party quickly achieved a significant result in the 1986 and 1988 elections. However, from its beginning, it was subjected to all sorts of harassment and attacks with specific violent attacks targeting its members. During the years 1991 and 1992, there were negotiations between the government of President Cesar Gaviria and the Guerrilla Co-ordinator Simón Bolivar, ${ }^{35}$ which ended when the People's Liberation Army (Ejército Popular de Liberación - EPL) kidnapped the former minister Algerino Durán Quintero who died in captivity due to health complications. After this failed attempt, during the administration of President Andrés Pastrana, a negotiation table was installed in 1999 and a demilitarised region was established in the locality of San Vicente del Caguán for the realisation of the peace dialogues. However, at the same time, Plan Colombia was implemented with financial collaboration from the Government of the United States of America to strengthen the Colombian armed forces. ${ }^{36}$ The FARC-EP also used the demilitarised region to continue their illegal activities and strengthen themselves. Apparently, at that time, the chosen delegates were seated together discussing peace, however, neither side showed any real motivation to negotiate or build peace. As a result, the negotiation table ended on 24 February 2002, due to the kidnapping of an airplane by the FARC-EP. ${ }^{37}$

Hopelessness for the achievement of peace with the FARC-EP was demonstrated by the Colombian people who elected President Álvaro Uribe Vélez in 2002. His election was based on the promise of recovering Colombian territory by force and destroying the guerrillas until the end of his mandate, through the strategic performance of the Colombian military with its government plan known as the 'Democratic Security' policy. This resolution of the conflict through the military route ended any possibility of dialogue with the guerrillas. After his two consecutive presidential terms, Uribe failed to deliver his initial promise, although he was able to carry out major military strikes against the guerrillas, including the deaths of some members of the FARC-EP secretariat and the recovery of part of the territories that were under guerrilla control.

At the end of 2012, the government of President Juan Manuel Santos publicly declared the beginning of the negotiations with the FARC-EP for the end of the armed conflict. ${ }^{38}$ The emerging negotiating agenda included five fundamental points of dialogue: rural development, establishment of guarantees for the exercise of political opposition and citizen participation of demobilised guerrillas, ending the armed conflict (ceasefire, disarmament and reintegration of demobilised combatants into civilian life), dismantling the guerrillas' drug trafficking business and victims' rights to truth and reparations. In addition to these points, the importance of consolidating a pluralistic political system was highlighted. To consider the last peace process, it is important to note that this was initiated only after the armed guerrillas had been in existence for 48 years, having been founded in 1964. Since its foundation, the FARC-EP has grown vertiginously. In the last year 
of the peace process (2016), the group submitted information to the national government about its combatants (a total of 5,765 members). ${ }^{39}$ The peace talks began with the installation of the negotiation table in the city of Oslo in Norway on 18 October 2012 and continued with its transfer on 6 November 2012 to Havana, Cuba. Among the negotiating participants of this last peace process were the delegation of the Colombian government, the FARC-EP delegation, representatives of the Colombian military working with the government delegation, international delegates, representatives of the Catholic Church, victims of the conflict and civilians. For Herbolzheimer, the Colombian peace process is renowned for the democratisation of the process, where the victims have been placed at the centre. Following this argument, it is the most attentiongrabbing agreement in the world to avoid impunity. ${ }^{40}$ However, contrary to Herbolzheimer's view, the process did not include the political opposition that always criticised how the dialogues were conducted.

After almost four years of negotiation, agreements were achieved on those five points of the agenda of dialogue in Cartagena de Indias (Colombia), on 24 August 2016. But a popular referendum rejected the agreement (the veto to the approval of the agreements won by 50 per cent to 49 per cent) at the beginning of October 2016. After the rejection of the first draft, the opposition's demands on the agreement were incorporated into the final document: 'the Final Agreement for the Ending of the Conflict and the Construction of a Stable and Lasting Peace'. ${ }^{41}$ With this new appellation, the text was signed between the two parties in a closed meeting on 24 November 2016 in Bogotá, Colombia. The document was then sent to the Congress of the Republic of Colombia for ratification and implementation, obtaining a fast-track procedure.

It is interesting to note that child soldiers were never an issue in previous negotiations between the government and armed groups. In fact, the initial agreement to start peace negotiations, signed by the FARC-EP and the Government on 26 August 2012, in Havana, did not mention the issue of child soldiers or the situation of those involved in the armed conflict. ${ }^{42}$ Civil society organisations, such as the Coalición contra la vinculación de niños, niñas y jóvenes al conflicto armado en Colombia (COALICO), expected that children could appear in the peace agreement under the discussions of victims. ${ }^{43}$ It was considered a victory for those fighting for this cause that the Final Agreement signed on 24 November 2016, in Havana, included children in general, especially those involved in the armed conflict.

Two things can explain the lack of attention to the issue of child soldiers in peace negotiations in Colombia. The first is that the recruitment and use of children in an armed conflict was already considered a violation of humanitarian law and of human rights presented in many international documents signed by Colombia. Hence, groups that utilised this resource would hide it 
to avoid losing international legitimacy and facing international accountability. The second explanation is that the use of child soldiers is a relatively new issue in the history of the conflict, so in previous negotiations, children were not yet involved in the armed groups as child soldiers. The use of child soldiers in Colombia started in the 1990s when the conflict had been ongoing for more than 25 years and guerrillas and paramilitary groups lacked human resources to fill their ranks and more areas in the country were affected by violence which directly impacted and dislocated families and children.

All parties involved in the Colombian armed conflict employed child soldiers in some capacity, including the Colombian Army for intelligence and information activities. Springer calculated that 18,000 children were directly involved in the armed conflict being part of guerrillas or post-demobilisation groups known as bandas criminales (BACRIM). ${ }^{44}$ Thus, 42 per cent of the FARC forces, 44 per cent of the ELN and 40 per cent of the Autodefensas Unidas de Colombia (AUC) members (who did not effectively demobilise themselves) were under 18 years old. ${ }^{45}$ Currently, BACRIM are the groups that recruit the largest number of children, making up more than 50 per cent of their forces. Besides that, another 100,000 children were involved in indirect activities of child labour, such as in the cultivation of coca and they could be easily involved in military activities. ${ }^{46}$

In 2008, children's recruitment age was 12.9 years old on average. In 2012, the average age was 12.1 years and 69 per cent of the recruited children had not yet reached 15 years old. Of all the children, 57 per cent are boys, but there was an increase in the number of recruited girls. An interesting fact is that 29 per cent of the children are indigenous. According to Springer's estimations, these are 674 times more likely to be directly affected by the conflict than other groups in Colombia. ${ }^{47}$

In Colombia, girls can represent between 25 per cent and 50 per cent of guerrilla and paramilitary groups. ${ }^{48}$ Most of these girls volunteer themselves as a mechanism for their emancipation and empowerment in a rigid, hierarchical and sexist social structure, ${ }^{49}$ to end sexual abuse and mistreatment at home and to have access to protection and survival. In this case, the armed group is a way to escape from an abusive and unfavourable family environment. ${ }^{50}$

Springer's estimations point out that 81 per cent of the child soldiers consider their recruitment as voluntary. ${ }^{51}$ The risk of re-recruitment is real in Colombia, especially because there are post-demobilisation groups who are not negotiating peace with the government. ${ }^{52}$ This is even more evident for girl soldiers who consider the guerrilla environment more equal than the Colombian society. On the other hand, children cite the security of being in an 'armed group as a 
major incentive to remain mobilised and the government's disinclination to offer ongoing funding or other promised assistance add even more difficulty' to demobilisation programmes. ${ }^{53}$

A difficulty that increases the possibility of the recruitment or re-recruitment of children is that there is little chance of those armed groups or people who recruited children being punished. This is an invisible crime among others connected with the armed conflict because there are few denouncers. According to the United Nations (UN), since 1999 only 193 people have been convicted of child recruitment and only two per cent of perpetrators of this crime have been denunciated. ${ }^{54}$ Another problem is that many adult combatants in armed groups within Colombia joined these groups when they were still children: about 52.3 per cent of ELN's adult combatants, 50.15 per cent of the adult members of the FARC and 38.12 per cent of the adults of the AUC. ${ }^{55}$

As part of the peace agreements between the government and the FARC, the Agreement for the Release of Children under 15 years old was signed on 15 May 2016. ${ }^{56}$ The FARC committed themselves to initially release all minors under 15 years old from their ranks and after that, all the children under 18 years old. International agencies such as the United Nations Children's Fund (UNICEF) and the International Organisation for Migration (IOM), the Special Representative of the Secretary-General for Children and Armed Conflict, the Carter Center and others are mentioned as entities chosen to help implement the procedures of this agreement.

The 2017 Report of the Secretary-General on the United Nations Mission in Colombia informed that the first 34 minors who left the FARC-EP camps on 15 and 16 August 2016 received the support of the International Committee of the Red Cross. ${ }^{57}$ Between September 2016 and August 2017, 122 children (56 boys and 66 girls) were released. The government provided continued care for 118 minors, in temporary care institutions (22), through family reunification (44), in foster families and temporary care centres (five). Nineteen of them are still in centres directed by IOM and UNICEF. Ten chose to go back to territorial areas to receive training and reintegration there and 18 who had reached 18 years old were transitioning to adult programmes. The report recognises challenges such as access to protection, education, healthcare, recreational activities and the design of a reintegration programme for families with young children. ${ }^{58}$

Cepero raises some critical points to consider about children's release from the FARC's ranks. ${ }^{59}$ The first one is that there are no clear numbers stating how many children the FARC has in their ranks. They initially said it was 21 , but this number must be higher considering that between 1999 and July 2016 the Instituto Colombiano de Bienstar Familiar (ICBF, Colombian Family Welfare Institute) received 6,035 children in its DDR programme and 60 per cent of them were from FARC. Knowing the exact number is necessary to avoid the 'hidden' demobilisation of children. Cepero recalls that after the demobilisation of the AUC, the ICBF received just 963 
children between 2003 and 2006. ${ }^{60}$ Considering that Human Rights Watch estimated that 20 per cent of its members were children and that 31,617 adults demobilised, a large number of the AUC's children were sent home without any support or killed to avoid commanders' accountability for their recruitment. ${ }^{61}$ Child soldiers have initiated the reintegration process defined by the agreements with the support of UNICEF and its partners, but, reinforcing Cepero's observations, there is much left unclear about the details of the programme. ${ }^{62}$

\section{The ambiguous representations of child soldiers in the Colombian peace agreement}

In the Final Agreement children are understood as victims, as defined by the Colombian Constitutional Court. ${ }^{63}$ With Sentence C-069/16 issued in February 2016, the Constitutional Court ruled that all child soldiers who left the ranks before they reached the age of 18 years old, regardless of which group they belonged to, should be considered victims of the armed conflict and must receive assistance, compensation and local reintegration in accordance with Law 1448 of 2011, known as the Law of Victims and Restitution of Lands (Ley de Victimas y Restitución de Tierras). ${ }^{64}$ This Law classifies victims according to its article 3 as people who individually or collectively have suffered damage for events occurring since 1 January 1985, because of violations of international humanitarian law or of serious and manifest violations of human rights during the internal armed conflict.

The Final Agreement defines former child soldiers as victims of the armed conflict. According to a report published by the Defensoria Del Pueblo Colombia,${ }^{65}$ children, especially since 1995, were the group most affected by the conflict. In 2014, there were 7,487,204 people registered in the victims' universal register (RUV) system, which means 12 per cent of the Colombian population were victims of the conflict. Among them, 2,237,04918 were children 29.88 per cent of all victims. ${ }^{66}$ This represents approximately 13.4 per cent of the total child population in the country. Among the child victims, 94.36 per cent of them were victims of forced displacement (this figure represents 2,110,832 children or 35 per cent of all forcibly displaced people). They were also victims of threats, killings, torture, kidnappings, forced disappearance and sexual violence among other crimes. The idea of the victim relates to traditional understandings of childhood as a period of development where child's rights should be guaranteed and protected.

A challenge to the Final Agreement is to avoid an ambiguous understanding of what it means to be a victim. Recalling that child soldiers tend to be categorised under the classifications of victims or perpetrators, the Colombian peace agreement does not clearly state ways to avoid 
children being seen as perpetrators. The socialisation of the child soldier within the armed groups becomes understood as an impediment to the restructuring of their societies. It means that children may be represented as a social threat since they were socialised in violent manners within the armed groups. ${ }^{67}$

According to this stereotype, child soldiers can retake their role as perpetrators because they have been torn away from their families and put within armed groups during their formative years. Since they have been robbed of the moral tutelage of parents, teachers and religious leaders, child soldiers presumably develop twisted values by living in armed groups condoning killing and savagery. ${ }^{68}$ Therefore, they could also be labelled as agents that challenge the post-conflict peace, making the healing processes and their integration into their communities far more challenging. In this case, it could mean that demobilised children rejected by their families and society will view other armed groups as alternatives to survive the post-conflict changes. In sum, if child soldiers are portrayed as perpetrators, the risk of re-recruitment increases, and they become actual threats to the sustainability of peace because they will continue to participate in the conflict through other means.

This ambiguous view is also present in UN reports on Colombia. The Representative of the Secretary-General for Children and Armed Conflicts, in its report on Colombia in 2016, states that Afro-Colombian and indigenous children living in rural areas were the most affected victims of the conflict. The organisation is concerned with the capacity of the government to address demobilised children's needs to avoid their re-recruitment by armed groups, specially the five main postdemobilisation groups: Los Urabeños or Autodefensas Gaitanistas de Colombia (also referred to as Clan Úsuga), Los Rastrojos, Águilas Negras, Los Paisas and El Ejército Revolucionario Popular Antiterrorista Colombiano - ERPAC (known after the demobilisation as Libertadores del Vichada). All this contributes to strengthening the perpetrator stereotype.

The Final Agreement deals with a number of situations related to the risk of children's rerecruitment, including mechanisms to fight, investigate and prosecute criminal organisations and their supporters like the post-demobilisation groups and successors of the paramilitary troops, and measures to fight child labour and to guarantee rights for children, especially those in rural areas (including rights to food, social development, health, education, housing and access to water and the eradication of poverty) ${ }^{69}$ It is also concerned with the promotion of non-stigmatisation and nondiscrimination of vulnerable groups, such as women, ethnic communities, children and youth and LGBTQ populations among others. ${ }^{70}$ This is especially necessary for children who were involved in the armed conflict because there is the risk that they will be stigmatised and discriminated against when they return to their communities and families. This is a critical issue that can prevent rerecruitment as well. 
Point 3.2.2.5 in the Final Agreement is dedicated to the reincorporation of minors who left the camps of the FARC-EP. It says that these children will be the object of special attention and protection and seeks to guarantee their rights, prioritising their rights to healthcare and education. The reintegration process for minors is guided by the Agreement of 15 May 2016, including the recognition of their rights as victims, prioritisation of community and family reunification, guarantees of the best interests of the child according to International Humanitarian Law and psychosocial support for these children. ${ }^{71}$

Another critical point is securing financial support during the post-conflict period. The Final Agreement states that all former members of FARC-EP who leave the ranks will receive a monthly allowance for 24 months and other financial compensation. This applies to young people, but it is not clear how former child soldiers will benefit from this decision. The scarcity of assets can transform individuals into potential child soldiers having to face strategic survival through decisions or choices. This means that in armed conflict environments, the constant attack of armed groups on the local population and the scarcity of resources may explain a child's decision to enter an armed group to the extent that it can offer protection and alternatives for survival. ${ }^{72}$ In this context, joining another armed group may become the only alternative for former child soldiers from FARC, who tend to face discrimination from their families and lack opportunities to economically maintain themselves. During their conscription, children had no formal education training. After their demobilisation, they will lack the necessary skills to access the labour market.

Another contributing element for increasing social representation of former child soldiers as perpetrators or potential challengers to the peace instead of peace-builders is related to their criminal responsibilities during the conflict. Unlike other cases of conflict involving child soldiers, for example in Sierra Leone, the Colombian Final Agreement does not concede free pardon and amnesty for all crimes. It states that crimes present in the Statute of the Rome (crimes against humanity, crimes of war and genocide), including the recruitment and use of children under 15 years old in the conflict, would not receive amnesty and indult. The Agreement for the Release of Children guarantees that children 14 years old and under will not be criminally accountable for their actions during the conflict and that children between 14 and 18 years old can receive amnesty for the crimes of rebellion and connected infractions. However, those children over 14 years old who committed crimes that do not qualify to receive amnesty or indult will have their cases analysed by the Special Jurisdiction of Peace (Jurisdicción Especial para la Paz). The Final Agreement creates a Special Jurisdiction to deal with this issue of perpetrators' accountability, which includes a Room of Amnesty and Indult as well as a Court for Peace among other structures. The Special Jurisdiction for Peace renounced the criminal persecution of people who participated directly or indirectly in the 
armed conflict when they were minors. ${ }^{73}$ This passage does not make clear how the Court will analyse cases of young people who entered the conflict while they were children but were already considered adults at the time of the signature of the Agreement.

In the Colombian case, children involved in the armed conflict are labelled as victims of the armed conflict and are ambiguously represented as risks that put pressure on the peace process because of the risk of re-recruitment and the social perception of them as threats. On the other hand, the Colombian agreements provide spaces to guarantee participation of these child victims as potential peace-builders or stakeholders.

The Agreement for the Release of Children under 15 years old reinforces the role of former child soldiers as peace-builders when it points out that they will participate in the execution of the programme designed to assist them and that their point of view will be respected. Its orienting principles are: the best interests of the child; recognition of rights, recognition of citizens' rights including the right of participation in the decisions affecting them, recognition of their condition as victims of the armed conflict, respect for their dignity and privacy, a guarantee of integral protection and security, participation in the execution of programmes, prioritisation of community and family reunification. It also includes the adoption of a differential focus on gender, age and ethnicity, with special attention paid to the rights of girls and the humanitarian characteristics of the measures and programmes.

In the Final Agreement section 'Victims', there is recognition of victims as citizens with rights and the importance of victims' participation to satisfy their rights to know the truth, of reparation and of a guarantee of non-repetition. ${ }^{74}$ If children involved in the armed conflict, among other child groups, are classified as victims of the armed conflict, it could be said that they have the right to participate in the processes assured by the Agreement. The Final Agreement recognises victims as citizens who had their rights violated and that they are important political subjects for the transformation of the country. ${ }^{75}$ It opens a gap to recognise the agency of former child soldiers.

Even though clear possibilities for participation are stated in the analysed documents, the role of former child soldiers as peace-builders should be taken with reservations in the Colombian context. First, being ex-participants in an armed conflict like the Colombian one and perceived as threats by their local communities makes their recognition as active participants in their communities difficult. Second, there are no clear mechanisms or paths to this participation. This suggests that, as victims, former child soldiers will only be able to participate in spaces granted by adults and in situations in which adults consider their voices and opinions should be heard. In other words, former child soldiers are peace-builders because they are considered victims, though only when it is convenient for those who negotiated and will implement the peace agreement. A clear 
example of this is that the Final Agreement refers to many Commissions and Councils to support the peace process, providing truth and reconciliation for the country. However, there is no explicit mention of how children will participate in these forums. Many parts of the Final Agreement promote the participation of the Colombian people. Passages such as, '[...] it is a matter to build a stable and lasting peace with the participation of all Colombians without exception ${ }^{76}$ and others which speak to the active participation of men and women in their communities and mechanisms for active participation and reparation in the design and assessments of programmes, projects and policies are present in the document. However, it is not clear if these refer only to the participation of adults or if children are included as well. For instance, there is the specific nomination of youth participation in the National Political Pact (Pacto Político Nacional) but not children.

Paradoxically, it is the definition (and representation) of child soldiers as victims that creates opportunities for children to participate in the peace-building process. It remains to be seen whether or not these opportunities will, in fact, be opened to children. Berents and McEvoy-Levy argue that, although they were victims of the conflict, 'youth involve themselves in myriad forms and spaces of everyday peace-building [as] a response to the ongoing exclusion of the experiences of youth in peace-building practices'. This happens because 'in situations of insecurity, violence and conflict it is people within everyday structures who mobilise and act to minimise risk, to foster relationships and to build structures and practices of peace'. ${ }^{77}$

Post-conflict peace-building should consider children and youths as leaders of their communities. For this to happen, not only are peace education and reintegration efforts necessary, but also training in leadership, conflict resolution, communication skills and trauma resilience. ${ }^{78}$ Community-based approaches to post-conflict reconstruction programmes (that is, informal peacebuilding efforts) tend to be more effective platforms to hear children's voices and assess their integration needs than the child-centric campaigns of International NGOs. ${ }^{79}$ In the words of Blattman, 'young people may utilize their experience of war to create opportunities for civic political participation'. 80

The participation of Colombian child soldiers in peace-building has a strong background ${ }^{81}$. Although we analysed the possibility of children's participation in the formal peace-building process, there are other alternatives of informal peace-building spaces and activities that recognise children's roles as agents for change in the post-conflict environment. Colombian children have been involved in the creation of 'peace communities' in the middle of the war zone. Approximately 12,000 peasants negotiated a return to the land on which they used to live using policies of nonviolence and advocacy for a peaceful resolution to the conflict. ${ }^{82}$ They 'represent a new kind of political power grounded in community integrity and moral courage' ${ }^{83}$ Children in the Colombian 
peace communities actively resist recruitment, speak out against the armed groups and campaign for peace. ${ }^{84}$

Another important element for supporting the participation of child soldiers in the Colombian post-conflict discussions is El Movimiento de los Niños por La Paz (Children's Movement for Peace, MNP). Led by youth and children, it involved 2.7 million young people across Colombia in a symbolic vote called the 'Children's Mandate for Peace and Rights' in which the 'candidates' were children's rights drawn from the Convention on the Rights of the Child, including the 'right to peace' and the 'right to love and family'. ${ }^{85}$ This was significant because, for the first time, many Colombian adults realised the extent of the conflict's impact on the younger generation, ${ }^{86}$ and that their participation is necessary for the construction of a lasting peace in Colombia. This demonstration of solidarity and political engagement, in combination with other works organised by the MNP, has led to various towns and regions involving children more frequently in decision-making processes ${ }^{87}$ Children, particularly those who have lived through conflict, have a wealth of knowledge and experience that can contribute to the establishment of lasting peace and stability in the Colombian post-conflict environment. Different experiences of girls and boys should be considered to construct peace in Colombia. If children can be agents in the conflict, they can also be agents in peace-building processes.

\section{Final remarks}

In sum, the situation of conflict and violence in Colombia contributes to constructing an ambiguous view of the children involved in the armed conflict. They are represented as victims with an uncertain possibility of participation in the documents. But they are also perpetrators of atrocities and, consequently, a threat to their societies which denies them the right to participate in the design of the best social conditions for their post-conflict reinsertion. Children are also labelled a threat to the continuity of the peace because of their risk of re-recruitment. Based on this understanding, children are portrayed as victims, but their socialisation within the armed groups is interpreted as the cause and effect of the perpetration of violence and social disorganisation.

The Colombian Final Peace Agreement and the Agreement for the Release of Children from the FARC ranks represent an important step in guaranteeing children's participation in the peace process. These documents understand children as agents and not merely victims but maintain the dyadic vision of former child soldiers as potential agents of peace-building along with that of victims and perpetrators. Both documents show that the conflict and violence in Colombia have socially constructed an ambiguous view of child soldiers. When a Colombian child decides to 
voluntarily enter an armed conflict, the option to participate in the conflict is seen as his/her best alternative to solve structural problems: immense social handicaps, inequality, machismo, racism, patriarchalism, poverty and violence. It could be inferred that if children were not in this situation initially, then perhaps they would not have chosen to participate in the conflict.

With this consideration in mind, the Final Agreement does not mean an end to the conflict and violence or other structural situations that may constrain children's options. Thinking in a logical manner which protects children's rights in the post-conflict agreement, former child soldiers should be actively considered in peace-building programmes to address their needs. It is their definition as victims that guarantees them the possibility of participation in the Final Agreement, but this participation is conditioned to specifically-granted spaces by adults. At the same time, children perceived as perpetrators are addressed as direct threats to peace because their decision to participate in the conflict prevents them from being integrated into and considered as agents of peace-building in their communities. They were perpetrators socialised in a cruel environment by armed groups that can be re-recruited by armed elements.

The most used definition of children is based on the ideas of vulnerability which takes them away from the political and economic arenas. The Colombian peace agreements strengthen that vision. At the same time, child soldiers challenge this definition because they fight and force their entrance into the political realm. The simple classification of child soldiers as victims and perpetrators of atrocities is not sufficient to understand the complexity of this phenomenon. They are also agents of their lives, agents of change in conflicts and peace-building processes and need to be considered as such during and after their demobilisation. The argument here is not that children cannot be considered victims of armed conflicts, they are, but the definition of victims as passive entities does not contribute to the construction of peace. Understanding children as peace-builders confronts the traditional classification of children and puts them in the political realm that was denied to them by practitioners and decision-makers.

The deconstruction of this ambiguous social representation is possible if the former child soldiers' roles of agent and participant are recognised as necessary for the peaceful resolution of the internal armed conflict as well as for the post-conflict reconstruction. This should be done in formal peace-building processes like the peace agreements analysed in this article, but also in informal peace-building spaces and activities that recognise the value of children's participation. Children's political participation has a threefold benefit: it engages children in a productive and positive fashion, assisting in getting them off the streets and away from situations of potential violence; it allows them a chance to have their opinions heard and included in a meaningful way; and it provides insights into the processes of peace-building that adults may not have. Children actively 
respond to their environment, creating opportunities and possibilities around them. Even in the face of an ongoing conflict, the children and youth leaders in the Colombian peace communities strive for political recognition and engagement. ${ }^{88}$

One major challenge to the post-conflict environment is the implementation of the agreements and resources to fund peace-building initiatives. A Final Agreement that recognises children's participation will be useless if concrete opportunities for participation are not created. Avoiding re-recruitment is another post-conflict challenge. A peace agreement with the FARC is not the end of the conflict because there are many post-demobilisation groups, such as the BACRIMs, that continue to recruit children to their ranks and to violate children's rights. Guaranteeing children a voice and platforms for their participation is a unique way to deal with the risk of re-recruitment and with their social perception as perpetrators because children know their motivations to participate in the conflict and what measures should be adopted to avoid them taking the same path they took before. A situation directly related to this is that many rebel adults were recruited as children. The government will have to face this situation, mostly to address the needs of youth who were already 18 years old when the parties signed the agreement.

Children who were directly involved in the armed conflict have special needs that should be addressed. These and all other children need to participate in the peace negotiation, implementation and construction for the achievement of a lasting and durable peace. Children need to be understood as peace-builders and leaders of today as well as tomorrow; to be represented in peace agreements and recognised as social and political agents. Children and young people are agents in international relations because they consume, they work, they participate, they fight and they construct peace. ${ }^{89}$

Since child soldiers are perceived as warriors involved in armed conflicts, their decision to participate often excludes them from the benefits and protection associated with the traditional concept of children. ${ }^{90}$ They lose the principal characteristics of vulnerability and fragility related to the traditional conception of a child but, at the same time, they are not recognised as agents of their lives. Besides active participation, other possible alternatives to dismantle this ambiguous perception of victim or warrior of demobilised child soldiers in the Colombian post-conflict environment involve the implementation of different activities to engage children in peace-building including sports, arts, theatre and cultural activities together with guarantees that the parties to the conflict will implement their commitment to peace. The Colombian Final Peace Agreement and the agreement to release children from FARC ranks guarantees children's participation in the peace process by recognising their roles as victims. These documents do not directly define children as peace-builders but assure them the right of participation to promote children's voices in the formal peace-building process. 


\section{Notes}

${ }^{1}$ Children should be considered people under 18 years old, as in the main definition of this concept in the first article of the Conventions on the Right of the Child from 1989.

${ }^{2}$ Pachón, 'La infancia perdida en Colombia',

${ }^{3}$ UNSC, 'Resolution 2250 (2015)'.

${ }^{4}$ UNICEF, 'Cape Town Principles and Best Practice'.

${ }^{5}$ República de Colombia, 'Acuerdo General para la terminación del conflicto'.

${ }^{6}$ A first version of the agreement was signed on 26 September 2016. But a national referendum chose not to accept the agreement on 2 October 2016. A new version of the document with some changes especially in the Victims section was then signed in November and implemented by the Colombian government.

${ }^{7}$ ICC, Rome Statute.

${ }^{8}$ Jacob, 'Children and Armed Conflict'; Watson, 'Resilience is its Own Resistance'; Brocklehurst, 'The State of Play'.

${ }^{9}$ Watson, 'Resilience is its Own Resistance'; Watson, The Child in International Political Economy.

${ }^{10}$ Watson, The Child in International Political Economy.

${ }^{11}$ Brocklehurst, Who's Afraid of Children?, 266.

12 Brocklehurst and Peters, 'Constructing and Deconstructing Child Soldier Narratives', 5.

${ }^{13}$ Brocklehurst, Who's Afraid of Children?; Brocklehurst, 'The State of Play'.

${ }^{14}$ Brocklehurst and Peters, 'Constructing and Deconstructing Child Soldier Narratives', 4.

15 Ibid., 7.

${ }^{16}$ Brocklehurst, 'The State of Play', 34.

${ }^{17}$ Rosen, 'Child Soldiers, International Humanitarian Law'.

18 Boyden, 'The Moral Development of Child Soldiers', 349.

${ }^{19}$ Dubinsky, 'Children, Ideology, and Iconography', 10.

${ }^{20}$ Monforte, 'Razing Child Soldiers', 194.

${ }^{21}$ Park, 'Other Inhumane Acts'.

22 Boyden, 'The Moral Development of Child Soldiers', 349.

${ }^{23}$ Schultheis, 'African Child Soldiers and Humanitarian Consumption', 32.

${ }^{24}$ Brett, 'Adolescents Volunteering for Armed Forces'.

${ }^{25}$ Whitman, 'Preventing the Use of Child Soldiers', 2. 
${ }^{26}$ Rosen, 'Child Soldiers, International Humanitarian Law', 98-99.

${ }^{27}$ ICRC, Children Associated with Armed Forces.

${ }^{28}$ Brett, 'Adolescents Volunteering for Armed Forces', 859.

${ }^{29}$ Boyden, 'The Moral Development of Child Soldiers', 356; Brett, 'Adolescents Volunteering for Armed Forces', 859; Park, 'Other Inhumane Acts', 319.

${ }^{30}$ Nosworthy, Children's Security in Post-Conflict Peacebuilding.

${ }^{31}$ Ibid., 2.

32 Ibid.

${ }^{33}$ Camacho and Rodriguez, 'Firm Exit and Armed Conflict in Colombia'; Echandía, Dos Décadas de Escalamiento del Conflicto Armado; Sanchez et al., 'Conflict, Violence, and Crime in Colombia'.

${ }^{34}$ An agreement of power alternation between 1958 and 1978, it was made between the conservative party and the liberal party, in which there was a considerable increase of social and political exclusion of minorities, unequal distribution of lands, repressive and selective social violence, corruption and social injustice.

35 The guerrilla co-ordinator was formed by the Revolutionary Armed Forces of Colombia-People's Army (FARC-EP), National Liberation Army (ELN) and the People's Liberation Army (EPL). The meetings were held in Tlaxcala, Mexico, in 1991 and in Caracas, Venezuela, in 1992.

${ }^{36}$ Plan Colombia provided military aid to the Colombian government and sought to contribute to development through the fight against drug trafficking.

${ }^{37}$ The FARC-EP kidnapped a commercial plane from the former airline Aires, with 37 people on board, the flight was travelling from Neiva to Bogotá. The guerrillas kidnapped the Senator Jorge Eduardo Gechem Turbay.

${ }^{38}$ In 2011, President Santos recognised that the situation in Colombia was an internal armed conflict and not turmoil or internal violence as former presidents classified the situation.

${ }^{39}$ These data were given in the middle of a forum at the Military University 'Nueva Granada', on 28 September 2016 in Bogotá by the Colombian Army General Javier Flórez who works in the Subcommittee of the End of the Conflict and is also head of Strategic Transition Command.

${ }^{40}$ Herbolzheimer, 'Multiple Paths to Peace'.

${ }^{41}$ From now on we will refer to this agreement as Final Agreement.

${ }^{42}$ República de Colombia, 'Acuerdo General para la terminación del conflicto'.

${ }^{43}$ Author interview with COALICO, Bogotá (Colombia), July 2014.

${ }^{44}$ Springer, Como Corderos entre Lobos. Some armed groups like AUC disappeared in 2006, because of governmental demobilisation programmes undertaken by the Uribe Government (2002- 
2010). However, to fill the vacuum left by the AUC, a lot of its former members were regrouped into other groups. BACRIMs, such as Los Rastrojos and Los Uruabeños, ascended to be a warehouse for smuggling and drug trafficking. They are currently the most responsible for human rights violations in Colombia, including displacement and forced recruitment of children.

${ }^{45}$ Springer, Como Corderos entre Lobos.

${ }^{46}$ Ibid.

47 Ibid.

${ }^{48}$ Spellings, 'Scratching the Surface', 22.

${ }^{49}$ Springer, Como Corderos entre Lobos, 23; Spellings, 'Scratching the Surface', 21.

50 Spellings, 'Scratching the Surface', 21.

${ }^{51}$ Springer, Como Corderos entre Lobos.

52 The ELN announced that they would start a peace negotiation with the Colombian government in March 2016.

${ }^{53}$ WarChild, Child Soldiers.

${ }^{54}$ UN, 'Children and Armed Conflict'. UN Doc. A/69/926-S/2015/409.

${ }^{55}$ Springer, Como Corderos entre Lobos, 27-28.

${ }^{56}$ República de Colombia, 'Acuerdo sobre la salida de menores'.

${ }^{57}$ UNSC, 'Report of the Secretary-General on the United Nations Mission in Colombia'.

${ }^{58}$ UN, 'Children and Armed Conflict'. UN Doc. A/70/836-S/2016/360'; UN, 'Children and Armed Conflict in Colombia (September 2011-June 2016)'. UN Doc. S/2016/837.

${ }^{59}$ Cepero, 'Postconflicto en Colombia'.

60 Ibid.

${ }^{61}$ Human Rights Watch, You'll Learn Not to Cry.

${ }^{62}$ Ibid.; Cepero, 'Postconflicto en Colombia'.

${ }^{63}$ República de Colombia, ‘Acuerdo Final para la terminación del conflicto', 3. We have analysed the version of 24 November 2016.

${ }^{64}$ República de Colombia, Corte Constitucional, 'Norma Sobre Medidas De Atención'; República de Colombia, Ministerio Del Interior, Ley 1448 de 10 Junho de 2011.

${ }^{65}$ Defensoria Del Pueblo Colombia, Justicia transicional.

66 The report and the agreement use the expression NNA - niños (boys), niñas (girls) and adolescentes (adolescents) - because of juridical definitions in Colombia.

${ }^{67}$ See Café, 'Construção Social das Crianças-Soldado'.

${ }^{68}$ Wessells, Child Soldiers, 141.

${ }^{69}$ República de Colombia, 'Acuerdo Final para la terminación del conflicto’, 82.

${ }^{70}$ Ibid., 32, 47, 82. 
${ }^{71}$ Ibid., 74.

72 Rosen, 'Child Soldiers, International Humanitarian Law'.

${ }^{73}$ República de Colombia, 'Acuerdo Final para la terminación del conflicto’, 297.

${ }^{74}$ Ibid., 124.

75 The original quote is in Spanish: 'el reconocimiento de las víctimas como ciudadanos y ciudadanas que vieron sus derechos vulnerados y como sujetos políticos de importancia para la transformación del país’ (p. 131).

${ }^{76}$ República de Colombia, 'Acuerdo Final para la terminación del conflicto', 6.

${ }^{77}$ Berents and McEvoy-Levy, 'Theorising Youth and Everyday Peace(building)', 116.

${ }^{78}$ Alias, 'Reinventing the Role of Children and Youth'.

${ }^{79}$ Schwartz, Youth and Post-Conflict Reconstruction.

${ }^{80}$ Blattman, 'From Violence to Voting', 245.

${ }^{81}$ McGill et al. 'Evaluating Children and Youth Participation'

${ }^{82}$ Sanford, 'The Moral Imagination of Survival', 52-53.

83 Ibid., 53.

${ }^{84}$ Berents, 'No Child's Play'.

${ }^{85}$ Carter and Shipler, 'And a Child Shall Lead'.

${ }^{86}$ Cameron, Out of War, 31.

${ }^{87}$ Carter and Shipler, 'And a Child Shall Lead'.

${ }^{88}$ Sanford, 'The Moral Imagination of Survival', 291.

${ }^{89}$ Watson, The Child in International Political Economy; Berents, 'No Child's Play'.

${ }^{90}$ Boyden, 'The Moral Development of Child Soldiers'.

\section{References}

Alias, Amirah M., 2015. 'Reinventing the Role of Children and Youth in Post-Conflict Peacebuilding'. Capstone Collection Paper, no. 2787. Available at: http://digitalcollections.sit.edu/capstones/2787 [Accessed 18 October 2017]. Please provide date accessed (it was made)

Berents, Helen, 2009. 'No Child's Play: Recognising the Agency of Former Child Soldiers in Peace Building Processes'. Dialogue e-Journal 6(2), 1-35

Berents, Helen and Siobhan McEvoy-Levy, 2015. 'Theorising Youth and Everyday Peace(building)'. Peacebuilding 3(2), 115-125.

Blattman, C., 2009. 'From Violence to Voting: War and Political Participation in Uganda'. American Political Science Review 103(2), 231-247. 
Boyden, Jo, 2003. 'The Moral Development of Child Soldiers: What Do Adults Have to Fear?'. Peace and Conflict: Journal of Peace Psychology 9(4), 343-362.

Brett, Rachel, 2003. 'Adolescents Volunteering for Armed Forces or Armed Groups'. International Review of the Red Cross 85(852), 857-866.

Brocklehurst, Helen, 2006. Who's Afraid of Children? Children, Conflict and International Relations. Ashgate, Aldershot.

Brocklehurst, Helen, 2015. 'The State of Play: Securities of Childhood - Insecurities of Children'. Critical Studies on Security 3(1), 29-46.

Brocklehurst, Helen and Krijn Peters, 2017. 'Constructing and Deconstructing Child Soldier Narratives. Conflict, Violence and Peace'. In Conflict, Violence and Peace, Geographies of Children and Young People, Vol. 11, eds. Christopher Harker and Kathrin Hörschelmann. Springer, Singapore, 71-87.

Café, Luisa F.F., 2011. 'Construção Social das Crianças-Soldado: representações e dilemas dentro do marco regulatório da ordem internacional do Pós-Guerra Fria [Social construction of Child Soldiers: representations and dilemas inside the regulatory framework of the PostCold War international Order]'. MA diss., Pontifícia Universidade Católica do Rio de Janeiro.

Camacho, A. and C. Rodriguez, 2013. 'Firm Exit and Armed Conflict in Colombia'. Journal of Conflict Resolution 57(1), 89-3116.

Cameron, S., 2001. Out of War: True Stories from the Front Lines of the Children's Movement for Peace in Colombia. Scholastic, New York.

Carter, L.R. and M. Shipler, 2005. 'And a Child Shall Lead: Children's Movement for Peace and Return to Happiness in Colombia'. In People Building Peace: Successful Stories of Civil Society II, eds. P. van Tongeren, M. Brenk, M. Hellema and J. Verhoeven. Lynne Rienner, London, 182-165. Please provide page extent (it was made)

Cepero, Paola González, 2016. 'Postconflicto en Colombia (14). Desvinculando niños de las FARC'. OpenDemocracy, [Postconflict in Colombia (14). Unlinking children from the FARC], 6 June. Available at: https://www.opendemocracy.net/democraciaabierta/paola-garz-ncepero/postconflicto-en-colombia-14-desvinculando-ni-os-de-las-farc [Accessed 10 March 2018]. Please provide translation of title (it was made)

Defensoria Del Pueblo Colombia, 2014. Justicia transicional: Voces y oportunidades para los niños, niñas y adolescentes en la construcción de la paz en Colombia. [Transitional justice: Voices and Opportunities for Children and Adolescents in the Construction of Peace in Colombia]. Bogotá, Colombia. Available at: 
http://www.defensoria.gov.co/public/pdf/Informecompleto_Justiciatransicional.pdf [Accessed 10 March 2018]. Please provide translation of title (it was made)

Dubinsky, Karen, 2012. 'Children, Ideology and Iconography: How Babies Rule the World.' The Journal of the History of Childhood and Youth 5(1), 5-13.

Echandía, C., 2006. Dos Décadas de Escalamiento del Conflicto Armado en Colombia, 1986-2006. [Two Decades of Escalation of the Armed Conflict in Colombia, 1986-2006]. Universidad Externado de Colombia, Bogotá. Please provide translation of title (it was made)

Herbolzheimer, C., 2015. 'Multiple Paths to Peace: Public Participation for Transformative and Sustainable Peace Processes'. kult-ur 2(3), 139-156.

Human Rights Watch, 2003. You'll Learn Not to Cry: Child Combatants in Colombia. Human Rights Watch, New York. Available at:

http://www.hrw.org/reports/2003/colombia0903/colombia0903.pdf [Accessed 10 March 2018].

International Committee of the Red Cross (ICRC), 2013. Children Associated with Armed Forces or Armed Groups. ICRC, Geneva. Available at:

https://www.icrc.org/eng/assets/files/other/icrc-002-0824.pdf [Accessed 10 March 2018].

International Criminal Court (ICC), 2002. Rome Statute of the International Criminal Court.

Available at: https://www.icc-cpi.int/nr/rdonlyres/ea9aeff7-5752-4f84-be94-

a655eb30e16/0/rome_statute_english.pdf [Accessed 10 March 2018].

Jacob, Cecilia, 2015. 'Children and Armed Conflict and the Field of Security Studies'. Critical Studies on Security 3(1), 14-28.

NOT CITED IN ARTICLE - please cite or delete from ref list It was deleted from the list. McGill, Michael, Claire O'Kane and Annette Giertsen, 2017. 'Evaluating Children and Youth Participation in Peacebuilding in Colombia, DRC and Nepal: Lessons Learned and Emerging Findings'. In People Building Peace: Successful stories of Civil Society II. eds. P. van Tongeren, M. Brenk, M. Hellema and J. Verhoeven. Lynne Rienner, London. NOT CITED IN ARTICLE - please cite or delete from ref list. If citing, please provide page extent. We cited this article in End note \#31

Monforte, Tanya M., 2007, 'Razing Child Soldiers'. Alif: Journal of Comparative Poetics 27, 169208.

Nosworthy, David. 2007. Children's Security in Post-Conflict Peacebuilding. Discussion Paper Developed for the United Nations Office of the Special Representative of the SecretaryGeneral for Children and Armed Conflict, June. Available at: 
http://www.dcaf.ch/sites/default/files/publications/documents/childrenper cent27s-securitypost-conflict-peacebuilding-nosworthy.pdf [Accessed 10 March 2018].

NOT CITED IN ARTICLE - please cite or delete from ref list. (it was made)

Pachón, Ximena C., 2009. 'La infancia perdida en Colombia: los menores en la guerra'. [The Childhood Lost in Colombia: the Minors in the War]. Working Paper Series, no. 15. Universidad Nacional de Colombia. Available at: http://pdba.georgetown.edu/CLAS\%20RESEARCH/Working\%20Papers/WP15.pdf [Accessed 10 March 2018]. Please provide translation of title (it was made)

Park, Augustine S.J., 2006. 'Other Inhumane Acts: Forced Marriage, Girl Soldiers and The Special Court For Sierra Leone'. Social \& Legal Studies 15(3), 315-337.

República de Colombia, 2012. 'Acuerdo General para la terminación del conflicto y la construcción de una paz estable y duradera, 26 de Agosto'. [General Agreement for the Ending of the Conflict and the Construction Of A Stable and Lasting Peace, 24 August]. Available at: https://peacemaker.un.org/sites/peacemaker.un.org/files/CO_26082012_General\%20Accord $\% 20$ to $\% 20$ End $\% 20$ the $\% 20$ Conflict $\% 20$ and $\% 20$ Build $\% 20$ a\%20Stable $\% 20$ Enduring $\% 20$ Pea ce.pdf [Accessed 10 March 2018]. Please provide translation of title (it was made)

República de Colombia, 2016. 'Acuerdo sobre la salida de menores de 15 años de los campamentos de las FARC-EP y compromiso con la elaboración de una hoja de ruta para la salida de todos los demás menores de edad y un programa integral especial para su atención [Agreement for the release of children under 15 years of FARC-EP camps and commitment to the elaboration of a roadmap for the departure of all other minors and a special comprehensive programme for their care]'. Comunicado Conjunto, no. 70. La Habana, Cuba, 15 May. Available at:

https://www.mesadeconversaciones.com.co/sites/default/files/comunicado-conjunto-70-15de-mayo-de-2016-1463349969.pdf [Accessed 10 March 2018].

República de la Colombia, 2016. 'Acuerdo Final Para La Terminación Del Conflicto Y La Construcción De Una Paz Estable Y Duradera, 24 August'. [Final Agreement for the Ending of the Conflict and the Construction of a Stable and Lasting Peace, 24 August]. Available at: http://www.urnadecristal.gov.co/sites/default/files/acuerdo-final-habana.pdf [Accessed 10 March 2018]. NOT CITED IN ARTICLE - please cite or delete from ref list. If citing please provie translation of title. We mentioned this document in the paper. This was the document of the first agreement that was not approved in the referendum. We believe that it is important to have this first version of the agreement in the References list, since we directly mention it in the introduction. 
República de la Colombia, 2016. 'Acuerdo Final Para La Terminación Del Conflicto Y La Construcción De Una Paz Estable Y Duradera, 24 de Noviembre'. [Final Agreement for the Ending of the Conflict and the Construction of a Stable and Lasting Peace, 24 November]. Available at: http://www.altocomisionadoparalapaz.gov.co/procesos-yconversaciones/Documentos\%20compartidos/24-11-2016NuevoAcuerdoFinal.pdf [Accessed 10 March 2018]. Please provide translation of title (it was made)

República de Colombia, Corte Constitucional, 2016. 'Norma Sobre Medidas De Atención, Asistencia Y Reparación Integral A Victimas Del Conflicto Armado Interno-Reclutamiento ilícito de niños, niñas y adolescentes'. Sentencia C-069/16, 2016. [Norms on Measures of Attention, Assistance and Integral Reparation to Victims of the Internal Armed Conflict Illicit Recruitment of Children and Adolescents. Sentence C-069/16, 2016]. Available at: http://www.corteconstitucional.gov.co/relatoria/2016/C-069-16.htm [Accessed 10 March 2018]. Please provide translation of title. (It was made)

República de Colombia, Ministerio Del Interior, 2011. Ley 1448 de 10 Junho de 2011 [Law 1448 of 10 June 2011]. Available at:

https://www.centrodememoriahistorica.gov.co/micrositios/caminosParaLaMemoria/descarg ables/ley1448.pdf [Accessed 10 March 2018].

Rosen, David M., 2007. 'Child Soldiers, International Humanitarian Law, and the Globalization of Childhood.' American Anthropologist 109(2), 296-306.

Sanchez, F., A. Solimano and M. Formisano, 2005. 'Conflict, Violence, and Crime in Colombia'. In Understanding Civil Wars, Vol. 2, eds. P. Collier and N. Sambanis. World Bank, Washington, DC, 119-159. NOT CITED IN ARTICLE - please cite or delete from ref list. (the article is cited in note \# 33 as Sanches et al)

Sanford, V., 2006. 'The Moral Imagination of Survival: Displacement and Child Soldiers in Guatemala and Colombia'. In Troublemakers or Peacemakers?: Youth and Post-Accord Peace Building, ed. S. McEvoy-Levy. University of Notre Dame Press, Indiana, 49-80 Schultheis, Alexandra, 2008. 'African Child Soldiers and Humanitarian Consumption.' Peace Review 20(1), 31-40.

Schwartz, S., 2009. Youth and Post-Conflict Reconstruction: Agents of Change. US Institute of Peace, Washington, DC.

. NOT CITED IN ARTICLE - please cite or delete from ref list. We deleted this citatiom. (it was made)

Spellings, Carolyn R., 2008. 'Scratching the Surface: A Comparison of Girl Soldiers from Three Geographic Regions of the World'. International Education 38(1), 21-39. 
Springer, Natalia, 2012. Como Corderos entre Lobos: Del Uso y Reclutamiento de Niñas, Niños y Adolescentes en el Marco del Conflicto Armado y la Criminalidad en Colombia. [As Lambs Among Wolves: the Use and Recruitment of Children and Adolescents in the Framework of Armed Conflict and Criminality in Colombia]. CODHES, Bogotá. Available at: https://www.centrodememoriahistorica.gov.co/descargas/informe_comoCorderosEntreLobo s.pdf. [Accessed 10 March 2018]. Please provide translation of title (it was made)

United Nations (UN), 2015 'Children and Armed Conflict'. Report of the Secretary-General. UN Doc. A/69/926-S/2015/409, 5 June. Available at: https://reliefweb.int/sites/reliefweb.int/files/resources/N1510923.pdf [Accessed 10 March 2018].

United Nations (UN), 2016. 'Children and Armed Conflict'. Report of the Secretary-General. UN Doc. A/70/836-S/2016/360, 20 April. Available at: http://www.securitycouncilreport.org/atf/cf/\%7B65BFCF9B-6D27-4E9C-8CD3CF6E4FF96FF9\%7D/s_2016_360.pdf [Accessed 10 March 2018].

United Nations (UN), 2016. 'Children and Armed Conflict in Colombia (September 2011-June 2016)'. Report of the Secretary-General. UN Doc. S/2016/837, 10 April. Available at: www.un.org/en/ga/search/view_doc.asp?symbol=S/2016/837 [Accessed 10 March 2018]. NOT CITED IN ARTICLE - please cite or delete from ref list. We cited this in the End note \#58

United Nations Children's Fund (UNICEF), 1997. 'Cape Town Principles and Best Practice on the Prevention of Recruitment of Children into the Armed Forces and Demobilization and Social Reintegration of Child Soldiers in Africa. Available at: www.unicef.org/emerg/files/Cape_Town_Principles(1).pdf [Accessed 10 March 2018]. United Nations Security Council (UNSC), 2015. 'Resolution 2250 (2015) adopted by the Security Council at its 7573rd meeting', 9 December. Available at: http://www.securitycouncilreport.org/atf/cf/\%7B65BFCF9B-6D27-4E9C-8CD3CF6E4FF96FF9\%7D/s_res_2250.pdf_[Accessed 10 March 2018].

United Nations Security Council (UNSC), 2017. 'Report of the Secretary-General on the United Nations Mission in Colombia'. UN Doc. S/2017/801, 26 September. Available at: http://www.un.org/ga/search/view_doc.asp?symbol=S/2017/801 [Accessed 10 March 2018]. WarChild, 2007. Child Soldiers: The Shadow of their Existence. WarChild, New York. Available at: https://reliefweb.int/report/world/child-soldiers-shadow-their-existence [Accessed 10 March 2018]. 
Watson, Alison M.S., 2009. The Child in International Political Economy: A Place at the Table. Routledge, Abingdon.

Watson, Alison M.S., 2015. 'Resilience is its Own Resistance: The Place of Children in PostConflict Settlement'. Critical Studies on Security 3(1), 47-61.

Wessells, M., 2006. Child Soldiers: From Violence to Protection. Harvard University Press, Cambridge, MA.

Whitman, Shelly, 2004. 'Preventing the Use of Child Soldiers: The Role of the International Criminal Court'. Group for Research and Information on Peace and Security (GRIP), Brussels. 